Article

\title{
Forest Conservation and Restoration Using the Emberger Index: Cork Oak as Study Case
}

\author{
Federico Vessella and Bartolomeo Schirone *
}

check for

updates

Citation: Vessella, F.; Schirone, B.

Forest Conservation and Restoration Using the Emberger Index: Cork Oak as Study Case. Forests 2022, 13, 252. https://doi.org/10.3390/f13020252

Academic Editor: Guntis Brūmelis

Received: 29 December 2021

Accepted: 1 February 2022

Published: 6 February 2022

Publisher's Note: MDPI stays neutral with regard to jurisdictional claims in published maps and institutional affiliations.

Copyright: (C) 2022 by the authors. Licensee MDPI, Basel, Switzerland. This article is an open access article distributed under the terms and conditions of the Creative Commons Attribution (CC BY) license (https:// creativecommons.org/licenses/by/ $4.0 /)$.
Dipartimento di Scienze Agrarie e Forestali (DAFNE), Università degli Studi della Tuscia, Via San Camillo de Lellis, 01100 Viterbo, Italy; vessella@unitus.it

* Correspondence: schirone@unitus.it

\begin{abstract}
The Mediterranean Basin is frequently stricken by huge disasters, and it represents an important biodiversity hotspot. Designing a synthetic approach, which is user-friendly with a low cost, that aims to summarize the main climatic factors that determine vegetation geographical ranges is a strategic solution to plan forest restoration actions and quickly act in cases of urgency. Here, we propose an updated version of the Emberger Index, applied to Quercus suber, an emblematic species of many ecosystems in the Mediterranean. Our investigation couples the latest spatially continuous climatic data, a high-resolution distribution map, and modelling techniques. The results evidence the effective benefits of the updated process, with insights into the optimal climatic requirements of a species within its real spatial domain, including projections for the next decades and the detection of putative refugia. Those outputs were not possible before because of a lack of data covering a certain area. Cork oak revealed an excellent study case, able to highlight the potentiality of Emberger's approach, and understand the ecological amplitude and vulnerabilities of the target species. If genetic information is available, the Emberger Index can even be applied at the haplotype scale, thus benefitting the applied research. Such an index mirrors the optimal plasticity and physiologic characteristics of a species, supporting the decision makers in selecting the correct plants to use in future reforestation and restoration activities.
\end{abstract}

Keywords: Emberger Index; Quercus suber; putative refugia; forest restoration; forecasting; assisted migration; Mediterranean bioclimate

\section{Introduction}

The Mediterranean Basin is a melting pot of human heritage, hosting different cultures, civilizations, lifestyles, and people who share a common climate. Hence, the Mediterranean area can be defined by observing its common climatic characteristics [1,2]. The apparent clearness of that concept hides many tricks because of the heterogeneity of the Mediterranean Basin, its complex orogenic history, and the consequential multitude of local environmental conditions [3]. Several attempts have been made since the beginning of the 20th century, by the scientific community, to draw the Mediterranean boundaries on a map. The major problem faced was associated with the selection of climatic limiting factors that determine the extension of the Mediterranean bioclimate; for example, Köppen [4] focused on the summer precipitation, Emberger [5] and Aschmann [6], following Giacobbe [7], considered the dryness degree during the warmest season, and Berenger [8] identified different boundaries imposed by summer wetness, winter coldness, climate dryness, or a combination of them. Presently, researchers agree that the seasonality and summer drought should be detected as global traits peculiar to that area, which are useful to fix the area's geographical limits. In particular, the summer is identified as the warmer season, with more droughts, i.e., a period of three months when both the lowest precipitation and highest temperatures are recorded. Based on this, Daget [1] combined the previous attempts, leading to the establishment of a summarized output, which was further improved and refined 
during the 1980s and 1990s [9-11]. Recently, Rivas-Martínez [12] refined the Mediterranean isoclimate by adding further indexes into a more complex system of formulas but focusing on the European countries (North Africa and the Middle East are presently excluded from his bioclimatic map). The use of climatic indexes has even been combined with vegetation descriptions, and the Mediterranean has been identified as an important biodiversity hotspot, considering the presence of peculiar ecosystems and species [6,13]. In the 1930s, Emberger empirically developed a bioclimatic quotient $(Q)$ that summarizes the main climatic factors that determine vegetation geographical ranges. In detail, the formula includes climatic variables, such as the annual precipitation $(P)$, the minimum temperature of the coldest month $(m)$, and the maximum temperature of the warmest month $(M)$, directly or indirectly expressing drought, continentality, and evapotranspiration [14]. The original formula from the 1930s is presented below (Formula (1)), while the same quotient, using Kelvin degrees for temperatures, instead of Celsius, was introduced by Daget in 1977 and led to Formula (2), as follows:

$$
\begin{gathered}
Q=\frac{100 * P}{M^{2}-m^{2}} \\
Q_{2}=\frac{2000 * P}{M^{2}-m^{2}}
\end{gathered}
$$

There are no significant divergences between those formulas, but Formula (2) is presently used more by researchers because of the higher precision, due to the employment of the Kelvin scale.

The main benefits of Emberger's expression rely on the facility to obtain raw data of the variables from any weather station, as well as the ability to draw, in a Cartesian diagram (namely, Emberger's diagram or a climatogram), the relation between $Q$ and $m$ for a given location; the latter is considered the main ecological limiting factor for plant species. The user-friendliness of Emberger's Index has ensured its wide application in technical reports, management plans, and guidelines, to describe and classify the climate of study sites [15-20]. The application of Emberger's method has even been extended to other research fields, other than ecology, for example, in biology to characterize the distribution of diseases' vectors, or in geology to map the geomorphological units [21,22]. In addition, by plotting $Q$ and $m$ of the areas where a target species is present, it is possible to bioclimatically characterize the species, encompassing all the points with a closed line. Therefore, the area delimited by that line on Emberger's diagram represents the phytoecological domain of the species. Such an output is worthy of mention because it offers an effective scheme of the main climatic requirements of a specimen; thus, it can help foresters to understand and select the appropriate species to adopt in reforestation or forest restoration plans.

Nowadays, several models are available to facilitate such interventions, for example, those based on niche ecological concepts [23,24], allowing the most appropriate species in a given area, in terms of pedological and climatic features, to be selected. Those models are conceived on complex algorithms that require large datasets, specific expertise, and high-tech hardware able to rapidly compute the calculations. For this reason, they are predominantly indicated for research purposes. In fact, foresters adopt alternative and user-friendly approaches in their investigations, and the Emberger's Index is one of the most employed approaches.

Although Emberger's bioclimatic diagrams are still in use and serve as references, the raw data are presently obsolete or incomplete; for example, the climatograms of Pinus halepensis Mill., Quercus ilex L., and Quercus suber L. were realized using a subset of weather stations closest to the target species' forests (mostly placed in North Africa, where Emberger and his followers conducted the majority of their field surveys), or with time series ranging from the 1930s to the 1970s [25-30]. If the climatic data are updated, as in the case of Quercus ithaburensis (Decne.), the investigation does not include the full species range [31]. In view of this, we consider it of paramount importance to address some quali-quantitative improvements, in order to fully characterize a target species that will benefit from advanced tools and a new set of climatic data. The renewal process is 
further required due to the ongoing global warming situation, which is causing changes in the Mediterranean climatic regime, with the possibility of leading to more severe drought conditions [32]. We can presently rely on global circulation model (GCM) simulations of the future climate, considering the different representative concentration pathways of greenhouse emissions [33]. Hence, given the detailed distribution of a species, it is possible to draw a complete and updated Emberger's climatogram for the present time and project the sites within it to the future. Hereafter, we refer to a keystone species of the Mediterranean Basin, cork oak (Quercus suber), as a study case to explore both the theoretical and practical benefits of applying Emberger's method, updated with the latest information about the species' occurrence and climate. The species was selected because its distribution fits with the Mediterranean limits proposed by Rivas-Martínez [12,24]. Moreover, it sustains rich biodiversity, many fundamental ecological processes (carbon storage, soil protection, water retention, etc.), and represents a valuable source of income for many countries [34]. Because of its importance, researchers have already gained a vast amount of knowledge about the ecology, physiology, distribution, genetics, etc., of the cork oak [35-37]. This allows us to refine our investigation, for example, differentiating the analysis according to the mainly detected haplotypes [38]. In addition, Emberger's Index was calculated for the detected potential refugia already proposed by Vessella et al. [36], to evaluate the expected future changes in the climate within those areas that are believed to have hosted the species since the last interglacial ( 130 ka), thus being crucial for the maintenance of the species in the next decades. We are confident about the usefulness of those outputs as effective tools for foresters to easily check the capacity of the cork oak to persist in a location, or to be successfully introduced into new areas.

\section{Materials and Methods}

The first step to actualize Emberger's Index for the target species is to obtain a detailed cork oak distribution, to properly identify the study area, i.e., the Mediterranean isoclimate, and to acquire the latest temperature and precipitation time series.

The actual range of cork oak was obtained from merging data from national inventories, field surveys and remote sensing analyses. The assemblage of the information required, first, standardization of the raw data; in fact, the accuracy of cork oak distribution suffers from heterogeneity among the countries around the Mediterranean. While Italy, France, Spain, and Portugal already have cork oak forests delimited and mapped as shapefiles of polygons, the North African countries lack high-resolution information. However, photointerpretation and local experts' support has led to definitive identification and delimitation of the species all around its actual range. A total of 155,209 polygons were mapped in GIS environment and stored on a geodatabase.

The study area limitation was chosen from the different proposals found in the literature. Here, we compared three Mediterranean isoclimates, as defined by Emberger [14,39], Daget [1], and Médail and Quézel [11]. Among them, we selected Daget's solution because it encompasses almost all the cork oak populations, more than the other isoclimates, except for the extra-zonal sites located in Aquitaine. To include the full dataset of cork oak stands, we extended Daget's limits to the Atlantic coast of Aquitaine.

The climatic variables used in Emberger's formula were retrieved from the WorldClim database, version 2 [40]. Annual precipitation, maximum temperature of warmest month and minimum temperature of coldest month were downloaded as raster grid files at 30 arc-seconds resolution $\left(\sim 1 \mathrm{~km}^{2}\right)$ and refer to the average climate data for 1970-2000. Concerning the simulation of the future climate, 13 IPPC5 projections from GCMs for the representative concentration pathway 8.5 (radiative forcing value of $+8.5 \mathrm{~W} / \mathrm{m}^{2}$ in the year 2100, relative to pre-industrial value) were used and the abovementioned variables were averaged using Spatial Analyst in ArcGis 9.3.1 for the following two time slices: 2050 (average for 2041-2060) and 2070 (average for 2061-2080) (Table 1). Hence, $Q$ values for 2050 and 2070 were computed as raster grids at 30 arc-seconds resolution, as the input data. The advantage of this information is its spatial extent, covering the full study area. 
Hence, Emberger's Index was calculated over the whole Mediterranean isoclimate, using the "Raster Calculator" function implemented in ArcGis 9.3.1, and the resulting raster grid was plotted on a $Q-m$ diagram (Supplementary Material 1). Similarly, cork oak populations were characterized according to Emberger's Index and the minimum temperature of the coldest month, both for present and future climate conditions. To assign those variables to each site, we ran the "Sample" function of the Spatial Analysis toolbox in Arcgis 9.3.1. The resulting tables, with the variables in columns and the species populations in rows, were used to realize Emberger's climatograms for the cork oak.

Table 1. List of global circulation models used to realize the consensus maps of bioclimatic variables for computing Emberger's Index for the future scenarios.

\begin{tabular}{cc}
\hline Model & Source \\
\hline Access 1-0 & https:// confluence.csiro.au/display/ACCESS (assessed on 22 September 2021) \\
BCC-CSM 1-1 & http://forecast.bcccsm.ncc-cma.net/ (assessed on 27 March 2012) \\
CCSM4 & http://www.cesm.ucar.edu/models/ccsm4.0/ (assessed on 1 April 2010) \\
CNRM-CM5 & http://www.cnrm-game-meteo.fr/spip.php?article126\&lang=fr (assessed on 2 September 2011) \\
GFDL-CM3 & http://www.gfdl.noaa.gov/news-app/story.32 (assessed on 1 July 2011) \\
GISS-E2-R & http://data.giss.nasa.gov/modelE/ar5/ (assessed on 31 January 2020) \\
HadGEM2-ES & https://verc.enes.org/models/earthsystem-models/metoffice-hadley-centre/hadgem2-es \\
(assessed on 17 March 2017) \\
INM-CM4 \\
IPSL-CM5A-LR \\
MIROC5 \\
http://igloo.atmos.uiuc.edu/IPCC/russ.sresa1b.pr.index.html (assessed on 1 December 2015) \\
MRI-CGM-LR & http://www.icesfoundation.org/Pages/ScienceltemDetails.aspx?siid=181 (assessed on 1 December 2015) \\
NorESM1-M & http://www.mpimet.mpg.de/en/science/models/mpi-esm/ (assessed on 1 December 2015) \\
http://cmip-pcmdi.llnl.gov/cmip5/availability.html (assessed on 1 December 2015)
\end{tabular}

Further investigations concerned the description of the potential refugia for cork oak, as identified by Vessella et al. [36], in terms of $Q$ and $m$. Present and estimated future values of those variables were calculated for 22 areas using the function "Extract by mask" implemented in ArcGis Spatial Analyst toolbox. The obtained raster values of each area were additionally plotted on a single Emberger's diagram to compare the variation across time.

A similar study involved the cork oak haplotypes retrieved from Simeone et al. (2009). In this case, each haplotype was treated separately; four climatograms were realized and compared with the climatogram representing the full species occurrence. The same was performed for the two future time slices (2050 and 2070). To estimate the optimal $Q-m$ conditions of the species, as well as the haplotypes, a kernel density function using Arcgis 9.3.1 was applied to the data points within Emberger's climatograms. We started from the assumption that more cork oak populations are present under certain $Q-m$ coupled values, and those values could be representative of an optimal climate condition for the species, at least in terms of Emberger's Index and the minimum temperature of the coldest month. The bandwidth of the kernel function was calculated using standard search radius automatically estimated by ArcGis 9.3.1, and the point density was therefore split into ten classes.

The five classes with the highest values were retained and plotted on Emberger's climatogram; this method concerned both present and future climates, so that the results of each haplotype could be compared. To point out the effects of global warming, the density classes of the haplotypes, for present and future conditions, were plotted on the same graph, taking the actual cork oak climatogram as the reference. This approach allowed the geographical position of those populations that will suffer a significant change in $Q$ and $m$ to be estimated and identified, so that their future position can be determined from the species climatogram. 


\section{Results}

The benefit of spatially calculating the climatic variables over the whole Mediterranean was that it resulted in an updated map of Emberger's Index at 30 arc-seconds resolution $\left(\sim 1 \mathrm{~km}^{2}\right)$. Here, we used the isoclimatic boundaries of the Mediterranean, as defined by Daget [1] (Figure 1). This dataset was used as the starting point to draw the real cork oak climatogram and compare it with previous calculations (Figure 2). In fact, the detailed distribution of cork oak has been plotted on Emberger's diagram, and the retrieved cloud of points shown as the results from Emberger during the 1930s better approximate the present cork oak $Q-m$ description than recent studies. However, the detailed species distribution we relied on allowed us to go beyond the mere description of the $Q-m$ limits for the species. If $Q$ ranges between 39 and 289 , and $m$ ranges between -4.2 and $8.9^{\circ} \mathrm{C}$, the spatial distribution of the cork oak population on the graph is not homogeneous. Hence, the application of the kernel function revealed at least four hotspots of high-density points, i.e., cores placed in the bottom right part of the graph, where sub-humid and semi-arid conditions rule. Those areas are characterized by narrow ranges of $Q$ and $m$, where the maximum concentration of real populations is observed (Figure 3 ). The most representative $Q$ values (of the highest density class) were as follows: 67 and 68 , coupled with $m$ of 3.5-4.1 ${ }^{\circ} \mathrm{C} ; 70$ and 71 , coupled with $m$ of $5.6-5.8^{\circ} \mathrm{C} ; 85$ and 98 , coupled with $m$ of $7.1-7.5^{\circ} \mathrm{C}$. All the pairwise combinations were grouped into 10 classes and listed in a sheet table, with a pivot table to be queried; thus, when given a couple of $Q-m$ values, it is possible to retrieve the density class they belong to (Supplementary Material 2).

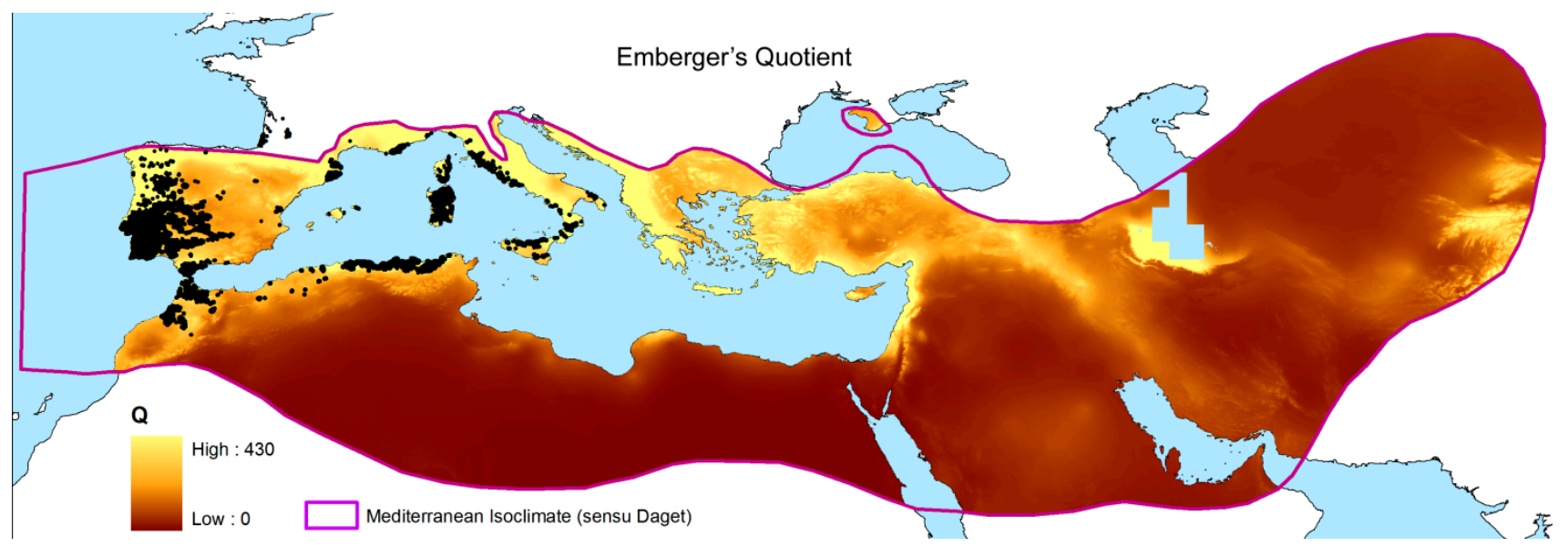

Figure 1. Map of Emberger's Index over the Mediterranean Basin at 30 arc-seconds resolution. The isoclimate of Daget [1] was used as reference to encompass the spatial calculation of Emberger's Q. Black dots show the real distribution of the cork oak.

The investigation of the putative refugia and haplotypes provided further results and insights, especially into the future relationships between the cork oak and climate. After analyzing and plotting the predicted changes in $Q$ and $m$ in the 22 refugial areas, a common trend can be observed (Figure 4). In fact, extracting the $Q$ and $m$ values of 2050 and 2070 from all the areas, a global increase in the minimum temperature of the coldest month (up to $12{ }^{\circ} \mathrm{C}$ ), coupled with a decrease in precipitation (thus, lower $\mathrm{Q}$ values, until the hyper-arid/arid limit), would interest all the potential species' refugia. This is clear from the graphs, where the ellipses tend to move towards the bottom-right corner of Emberger's diagram, although with different magnitude. In fact, given that the cork oak climatogram is fixed (i.e., assuming that the species climatic niche breadth is stable for the next century), some areas would partially or totally shift out of it. The former case is represented by 16 out of 22 areas, and the latter by 4 out of 22 (all of them belong to North Africa). In two cases, the Douro Valley, and the Var, all the $Q-m$ values predicted for the next decades would still be included within the cork oak climatogram. 


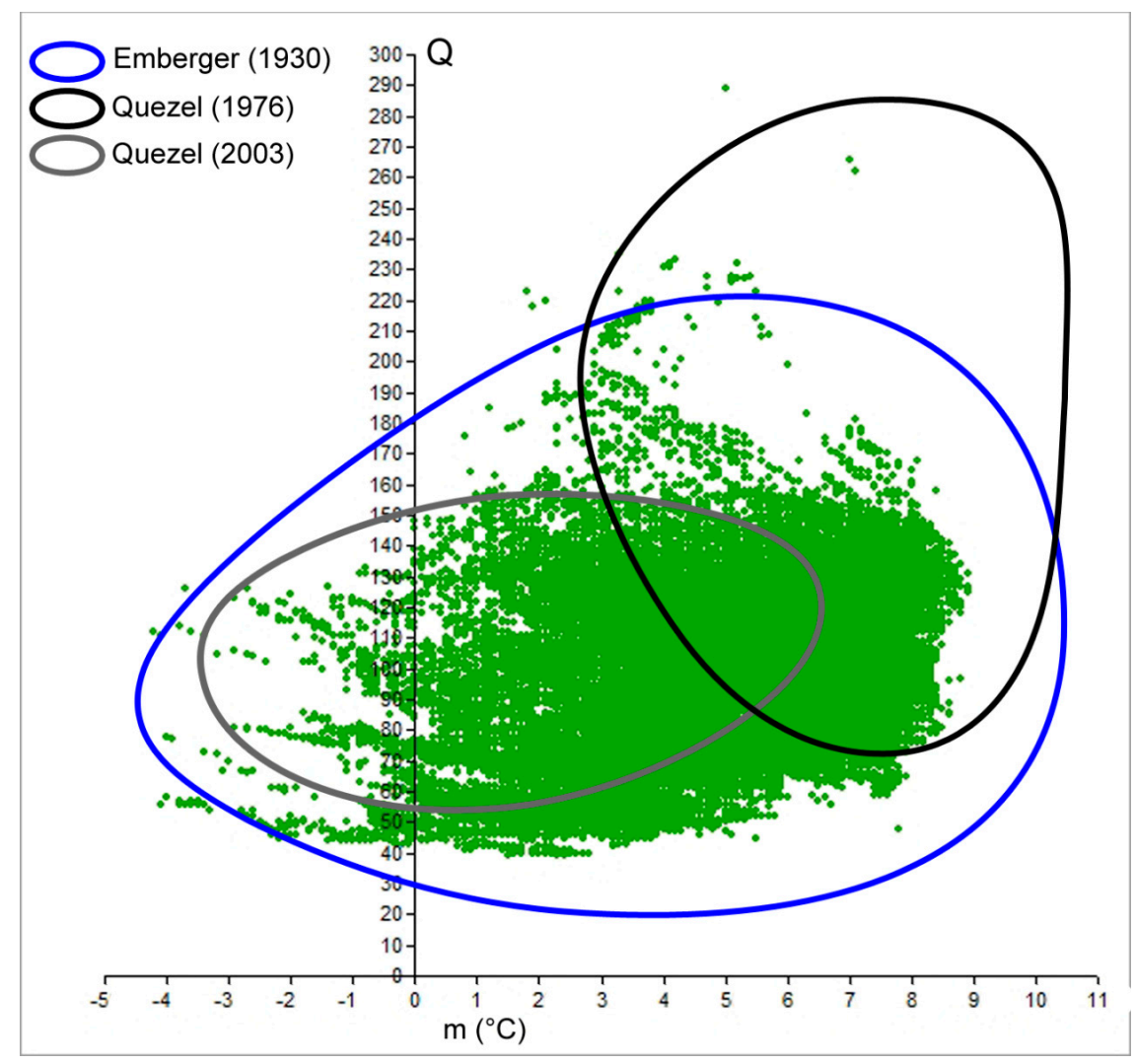

Figure 2. Comparison of cork oak climatograms as reported by Emberger [14] and Quézel [26,30] with the cloud of points of the real distribution at present time (green dots).

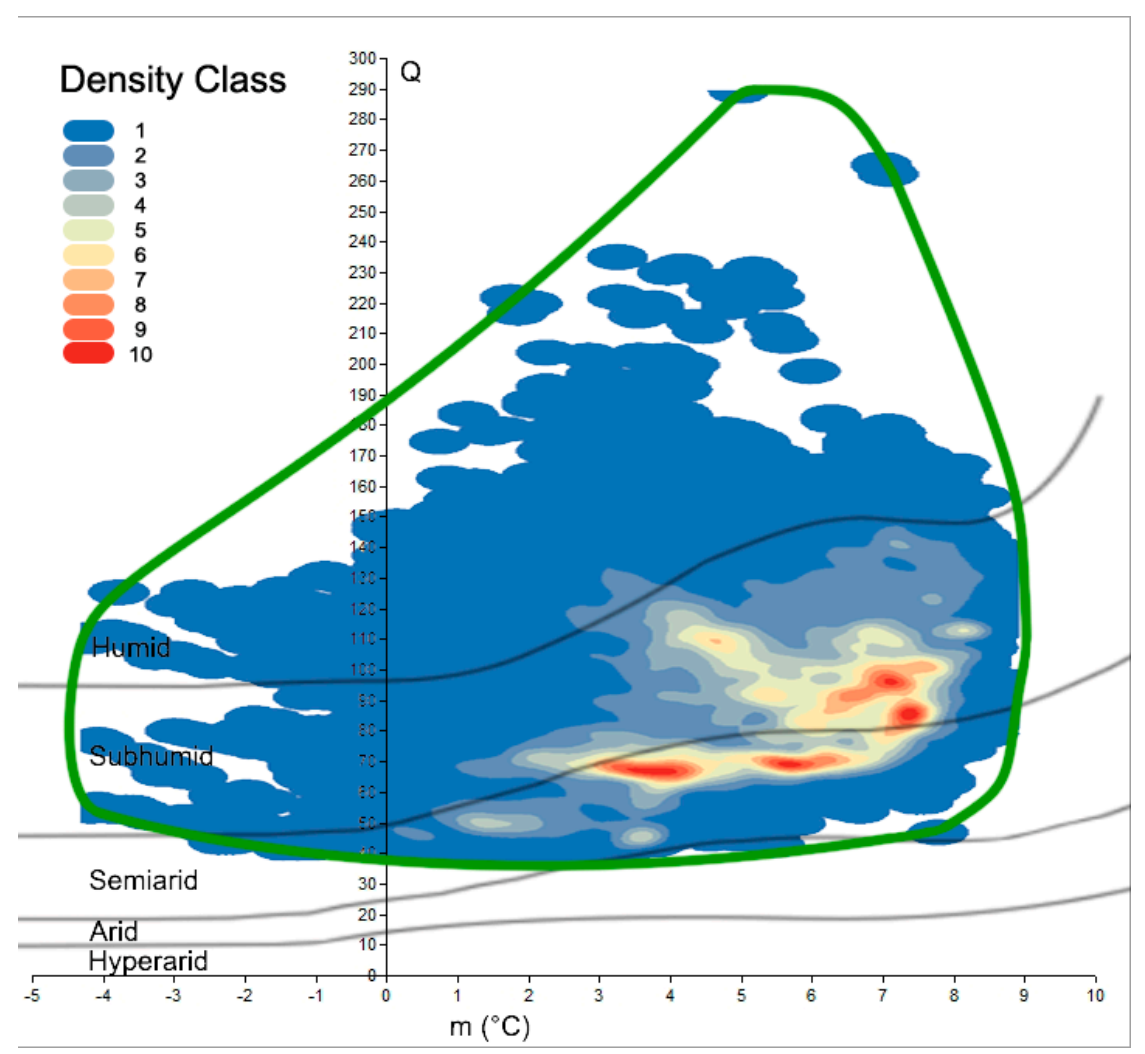

Figure 3. Kernel density classes of cork oak's points plotted on Emberger's diagram; blue to red scale shows lower to higher density magnitude. Green curve represents the species climatogram. 

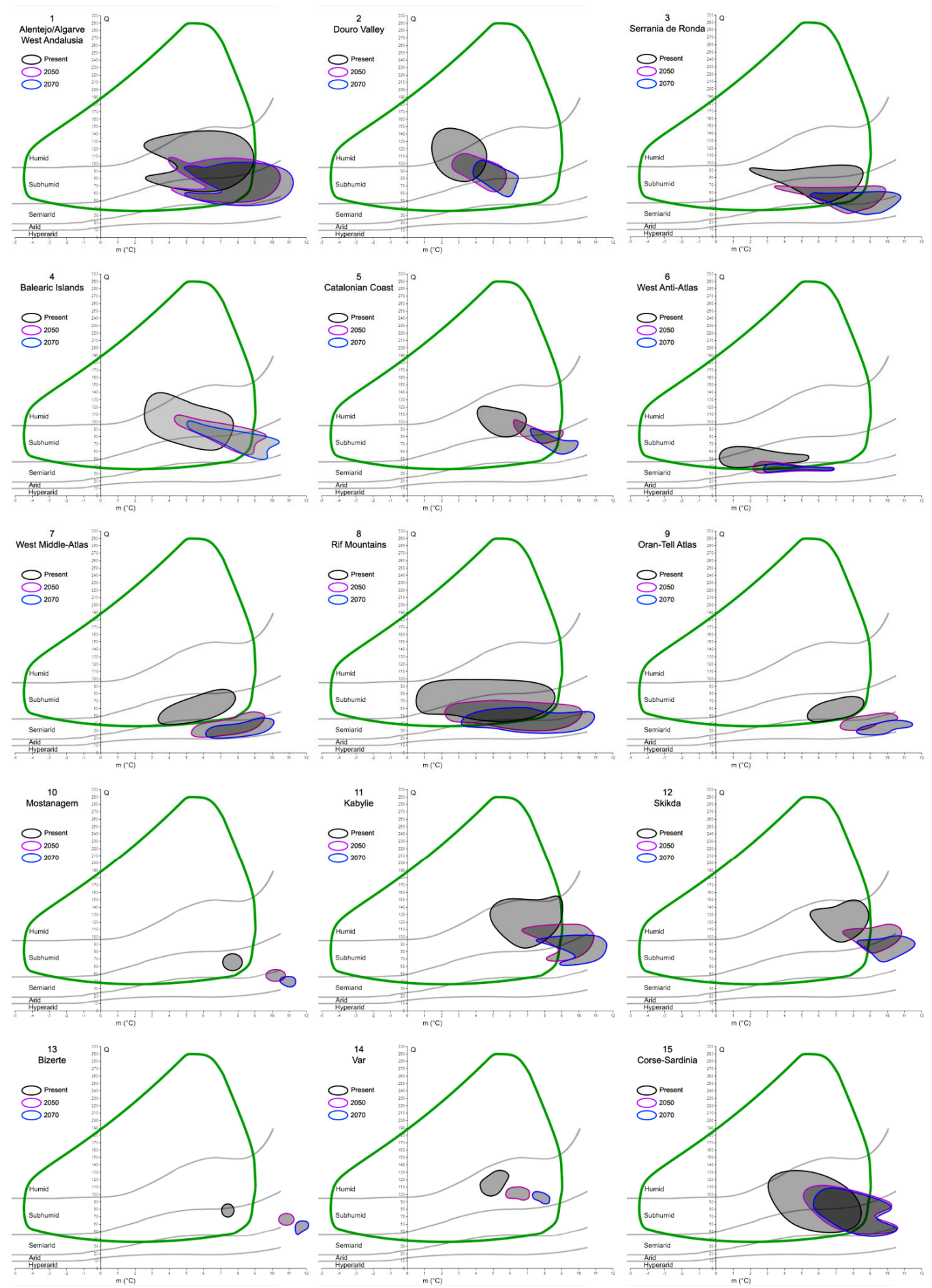

Figure 4. Cont. 

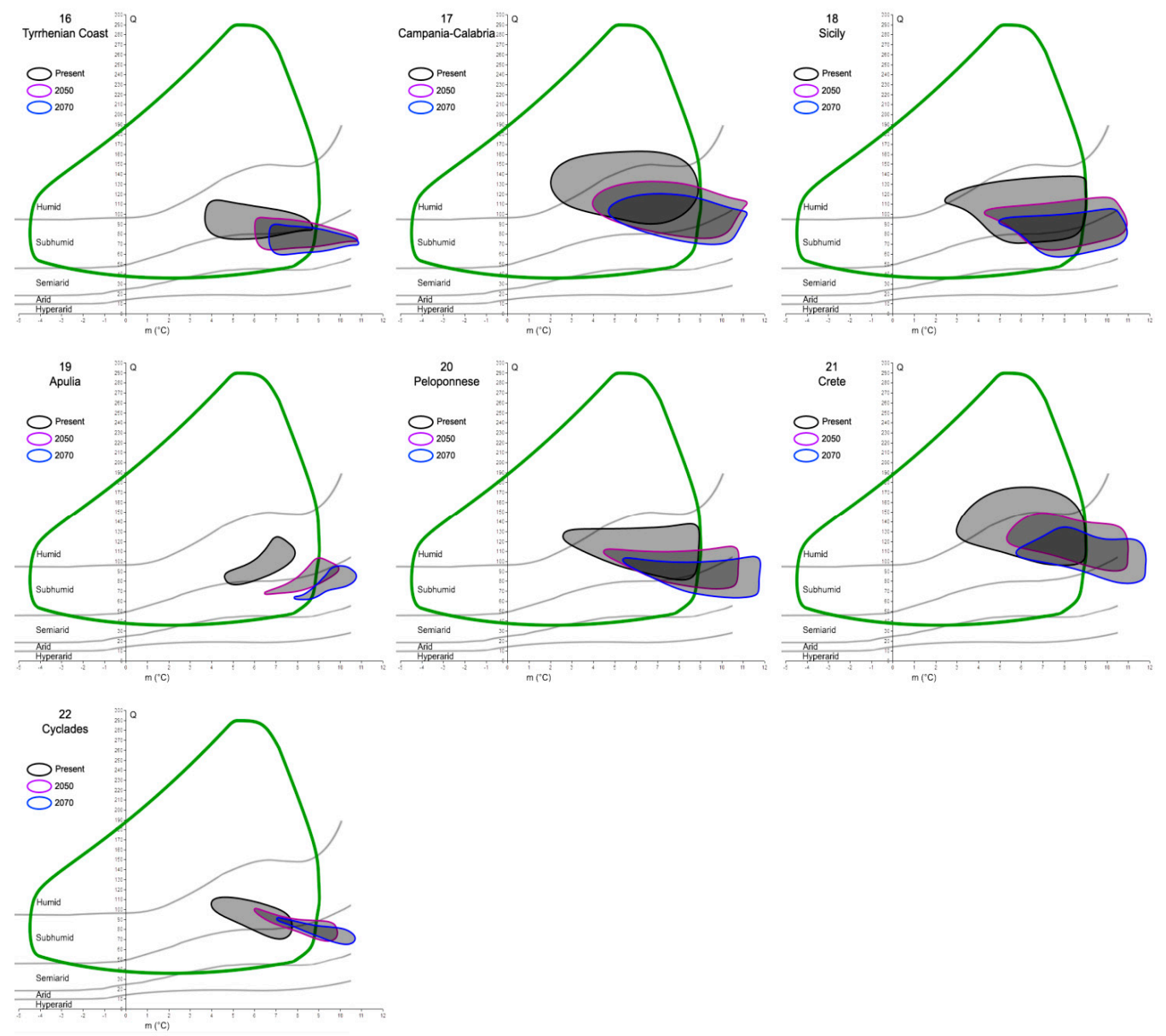

Figure 4. Mosaic of Emberger's climatograms for the 22 cork oak putative refugia proposed by Vessella et al. [36]. Black closed lines encompass the $Q-m$ values detected within each area at present time. Purple and blue lines show what the $Q-m$ values of the same areas would be in 2050 and 2070, respectively. The green curve represents the cork oak climatogram, as in Figure 3.

Focusing on the main haplotypes of the cork oak, as detected by Simeone et al. [38], we found different behaviors and responses to global warming. In fact, at present, the five highest density classes of each haplotype mostly occupy distinct spatial areas within the cork oak climatogram (Figure 5). The orange haplotype, with $Q$ ranging from 84 to 113, and $m$ from 3.1 to $4.2{ }^{\circ} \mathrm{C}$, is fully within the sub-humid domain, as is the blue haplotype ( $Q$ values from 91 to 115 , and $m$ from 3.4 to $6.4^{\circ} \mathrm{C}$ ). The latter is partially overlapped with the green haplotype, characterized by the following two main cores: the first is within the sub-humid space ( $Q$ from 102 to 122 , and $m$ from 3.9 to 5.1 ), and the second is within the semi-arid belt ( $Q$ centered around 50 , and $m$ from 1.5 to $2{ }^{\circ} \mathrm{C}$ ). Finally, the purple haplotype, which has its highest density classes covering a large portion of the species climatogram, is over both the semi-arid and sub-humid domains; its $Q$ values range from 63 to 114, while $m$ is between 2.7 and $8.2{ }^{\circ} \mathrm{C}$. When the future $Q-m$ values of the same areas are plotted on Emberger's graph, it will be possible to recognize the shift in those sites towards more drought conditions (Figure 6). In fact, most places in which the orange haplotype presently occurs have moved from the sub-humid domain to the semi-arid domain in less than one century, but persist within the cork oak climatogram. The same feature is observed in reference to the blue haplotype. In this case, the increase in the minimum temperature in 2070 places the core of the points slightly outside of the species climatogram. The green haplotype is in line with the previous haplotypes; a trend towards more drought conditions is observed as well, with the smallest core of points dislocated within the arid belt in 2070, thus outside of the climatogram. The purple haplotype seems to suffer from 
the future climatic scenarios more than the other haplotypes. Its major occurrence is presently characterized by sub-humid/semi-arid conditions, but in the next decades, those clouds of sites will all be placed within the semi-arid belt and partially outside of the cork oak climatogram, thus not theoretically being suitable for the persistence of the species. A qualitative representation of those changes is shown in Table 2.

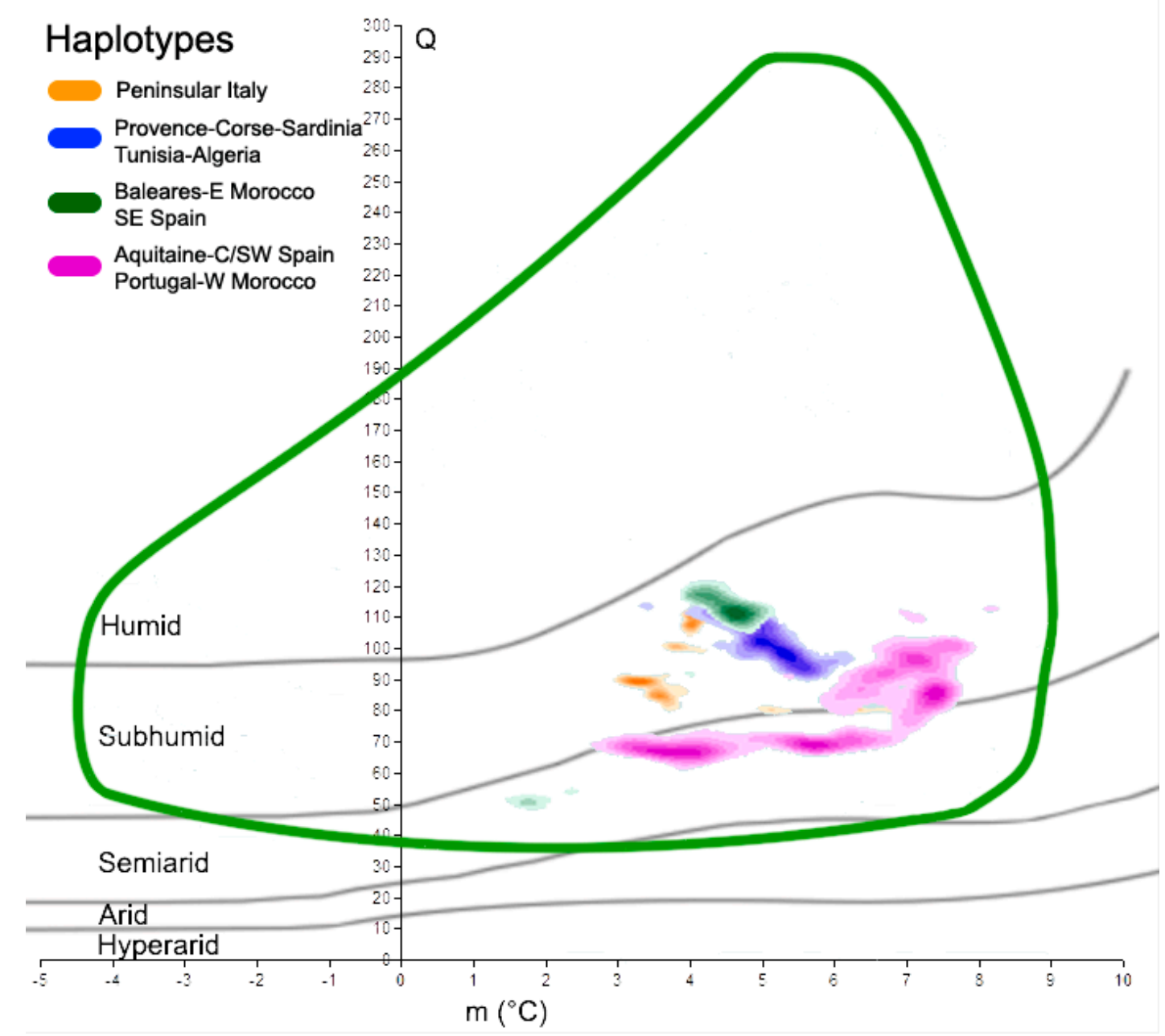

Figure 5. Selection and plot of the five highest density classes, at present, for each haplotype on Emberger's diagram in comparison with cork oak climatogram (green curve). The darker the subtle color of each haplotype, the higher the density of real points at certain $Q-m$ values.

Table 2. Minimum, mean and maximum values of $Q$ and $m$ parameters for the haplotypes investigated in this study. Present, 2050 and 2070 time slices are reported for comparison.

\begin{tabular}{ccccccccccccc}
\hline & \multicolumn{3}{c}{ Orange } & \multicolumn{3}{c}{ Blue } & \multicolumn{3}{c}{ Green } & \multicolumn{3}{c}{ Purple } \\
\hline $\mathbf{Q}$ & Today & $\mathbf{2 0 5 0}$ & $\mathbf{2 0 7 0}$ & Today & $\mathbf{2 0 5 0}$ & $\mathbf{2 0 7 0}$ & Today & $\mathbf{2 0 5 0}$ & $\mathbf{2 0 7 0}$ & Today & $\mathbf{2 0 5 0}$ & $\mathbf{2 0 7 0}$ \\
\hline Minimum & 84 & 69 & 63 & 91 & 73 & 65 & 50 & 38 & 35 & 63 & 48 & 43 \\
Mean & 96 & 82 & 77 & 102 & 88 & 80 & 103 & 91 & 84 & 82 & 63 & 57 \\
Maximum & 113 & 99 & 92 & 115 & 102 & 94 & 122 & 105 & 93 & 114 & 83 & 83 \\
\hline m & & & & & & & & & & & \\
\hline Minimum & 3.1 & 5 & 6.2 & 3.4 & 5.1 & 5.9 & 1.5 & 3.1 & 4.1 & 2.7 & 4 & 4.9 \\
Mean & 3.6 & 6 & 7.1 & 5.1 & 7.1 & 7.9 & 4 & 6.1 & 7.3 & 5.9 & 7.2 & 8.1 \\
Maximum & 4.2 & 8.9 & 9.9 & 6.4 & 9 & 9 & 5.1 & 7.2 & 8.2 & 8.2 & 9.2 & 10.3 \\
\hline
\end{tabular}



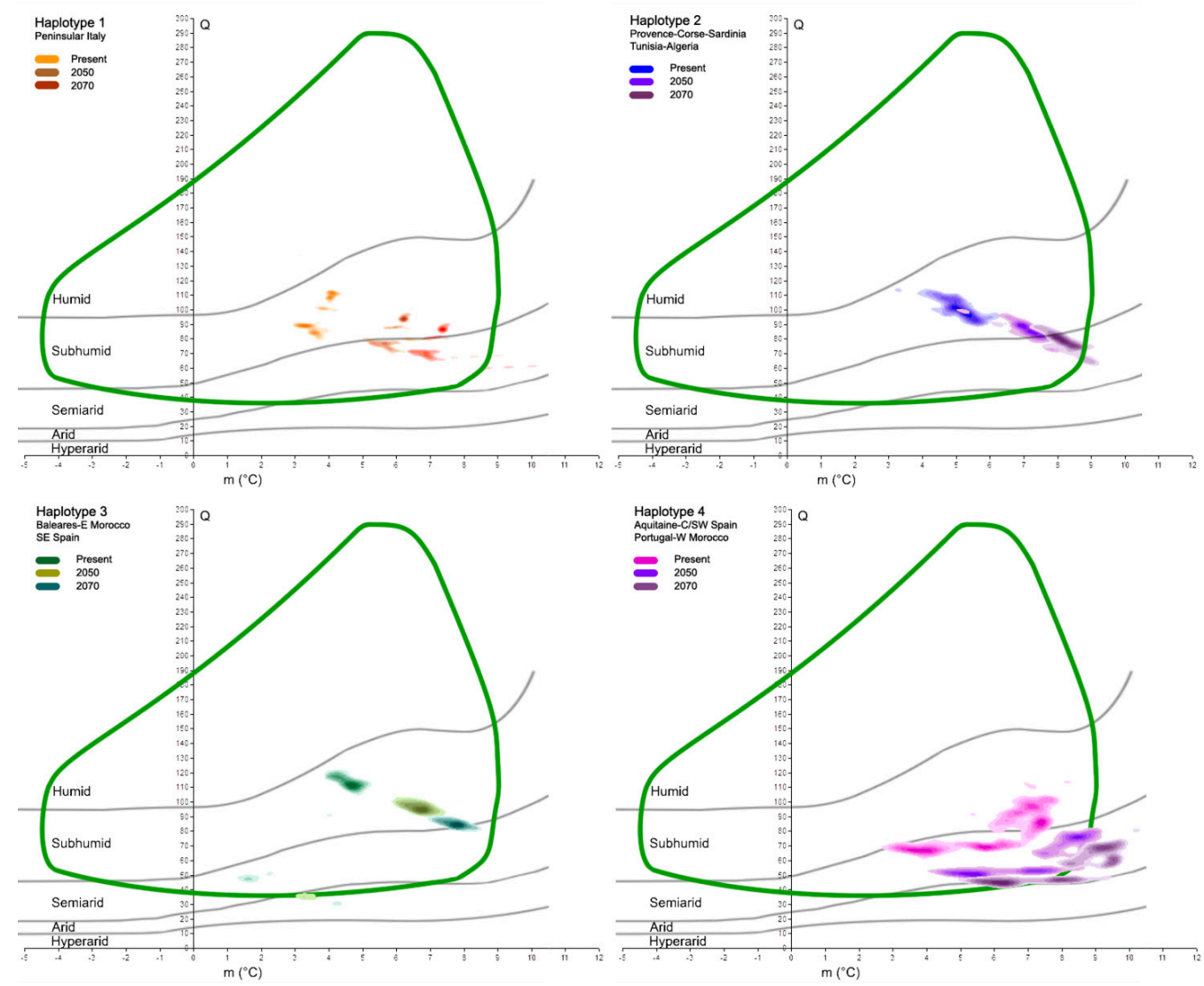

Figure 6. Projections of results shown in Figure 5 to 2050 and 2070 time slices. Each box shows the comparison of a haplotype at present and in the future. Cork oak climatogram (green curve) is used as reference.

The points outside of the species climatogram have been spatially represented on a map (Figure 7). Hence, loss of the present surface can be geographically localized and estimated (Table 3). A global reduction in cork oak occurrence within the same areas of the present distribution is observed. The results in Table 3 show that only $47 \%$ of the present cork oak sites would maintain $Q-m$ values suitable for the persistence of the species until the end of this century. Such a reduction is widespread over the whole range, but is mostly focused on the Iberian Peninsula (central and south-west) and North Africa. On the other hand, northern populations seem to better tolerate the increase in droughts and temperatures, as can be observed in French, Catalonian, Northern Portuguese, and Tyrrhenian cork oak stands. In fact, they persist throughout global warming, with a limited reduction in surface. Focusing on haplotypes, the purple haplotype would majorly suffer from the effects of a drier climate; there would be up to a $62 \%$ decrease in its present distribution at the end of the century. Each of the other haplotypes would undergo a theoretical reduction of ca. $35 \%$.

Table 3. Estimated reduction in cork oak populations, distinguished by haplotype, due to change in temperature and precipitation, as predicted for 2050 and 2070 by the thirteen global circulation models listed in Table 1. Numbers refer to residual surfaces expressed as cells of 1 square kilometer containing cork oak forests. The geographical location is shown in Figure 7.

\begin{tabular}{cccccc}
\hline & Orange & Blue & Green & Purple & Total \\
\hline Present & 2707 & 8970 & 12,929 & 51,773 & 76,739 \\
2050 & 2274 & 7866 & 11,120 & 35,771 & 57,031 \\
2070 & 1819 & 5963 & 8359 & 19,710 & 35,851 \\
\hline
\end{tabular}




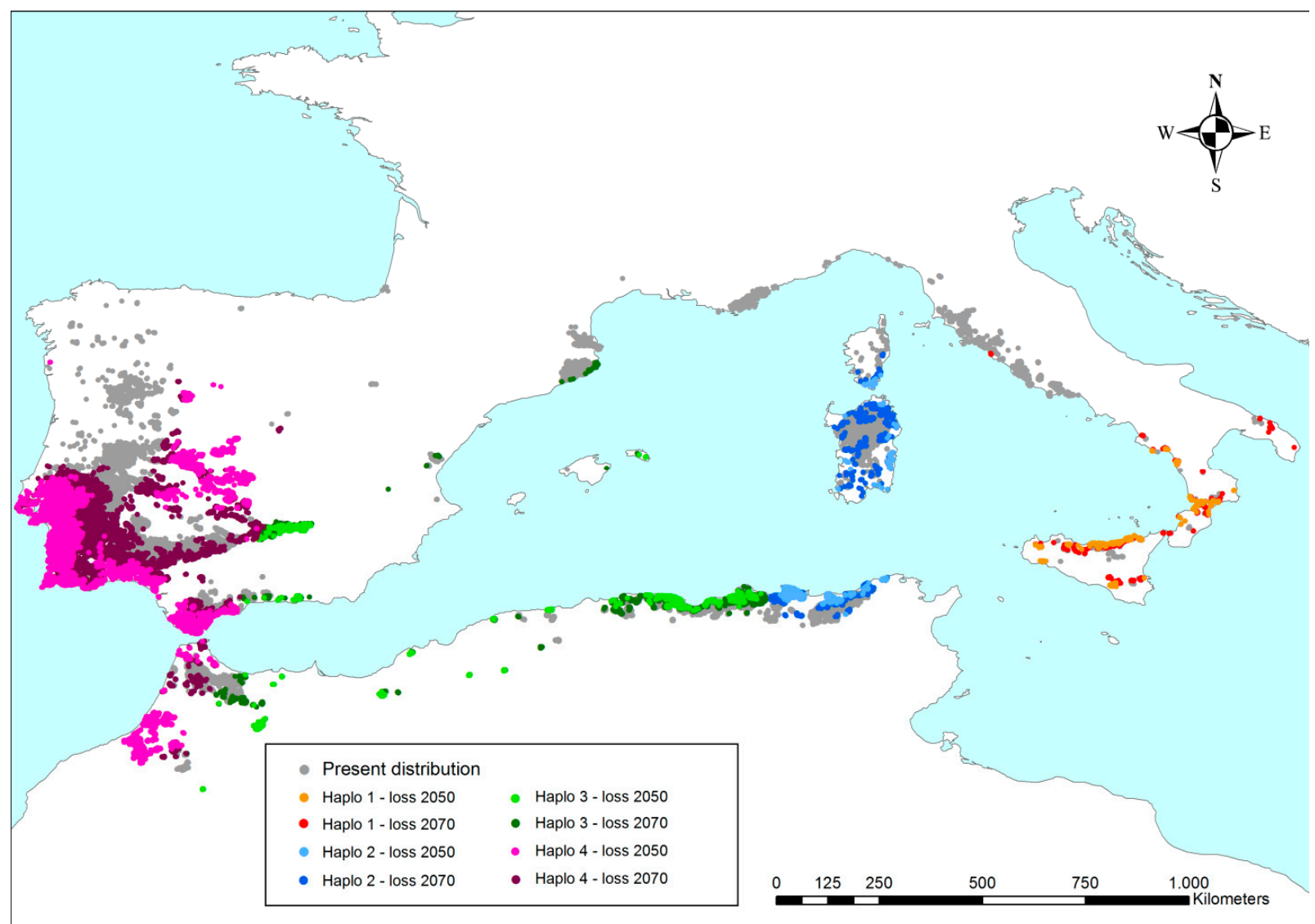

Figure 7. Cork oak distribution in the Mediterranean. Colors refer to haplotypes and to the areas that will have $Q-m$ values outside of the species climatogram in the next decades (see Figures 4-6); thus, they are not climatically suitable for the persistence of cork oak. Grey areas represent those sites where the species will keep safeguarded to increase their probability of enduring the conditions over time.

\section{Conclusions}

Environmental disasters strike many countries worldwide, and humans are fully responsible for much of the damage caused to forests. Hydrogeological instability and forest fires are frequent and natural, and the processes of regeneration are not enough to restore the ecosystems, given the high frequency of those episodes. Climate change is acknowledged to have strong implications for the integrity of ecosystems and the survival of species [41-44]. Wars and civil disorders are further factors menacing forests in some hotspots, such as the Middle East and North Africa [45]. The Mediterranean Basin is particularly sensitive to those threats, and the status of the forests in these hotspots mirror the ongoing processes mentioned above [46]. Humans are imposed to directly intervene with restoration actions, including species-assisted migration, reforestation, and defragmentation plans [24,47,48].

On the other hand, the urgent need for interventions and the dimensions of the target areas mean that fast, broadly available solutions that are user-friendly with a low cost are required. Methods or synthetic indexes fulfil those requirements, and several agencies have already adopted them in applied research [49].

Since its creation, Emberger's Index has been broadly adopted to synthesize the phytoclimatic characteristics of a study site. The feasibility of obtaining raw data and applying the formula has resulted in it becoming a successful solution, as demonstrated by its large employment in technical reports, applied research, and forest projects after more than 90 years since its creation [50,51]. In this study, we analyzed Emberger's climatogram for cork oak commonly used by experts to characterize the suitability of an area to host the species with reforestation plans. Once the models are assessed for other species, we 
believe that Emberger's Index could be easily used by foresters and experts involved in forest restoration and reforestation projects of the Mediterranean ecosystems [52,53]. The results evidenced the efficacy of the method but suggested the need for updated raw data to be implemented into the formula. Indeed, differences arose in the $Q-m$ values among previously proposed climatograms and the climatogram we realized, so their shapes differ significantly. Figure 2 clearly shows those divergences, among the pair "Quezel 1976-2003" and "Emberger 1930-our result" in particular, mainly due to the sample used. In fact, the original Emberger climatogram better approximates the real climatogram (cloud of green dots) because the data collection is distributed homogenously around the Mediterranean. With the updated process, characterization of the species now benefits from complete and detailed distribution; thus, the climatogram shows the real spatial domain according to the present occurrence of the target species. At the same time, it is important to be reminded that inventories based on only remote sensing do not enable detailed range reconstruction, while field surveys remain strategic to create a real distribution map.

New advances from the same detailed distribution and its employment in the Emberger criteria were found; given the full species occurrence, it was possible to correlate the spatial abundance of the cork oak and climatic values, demonstrating the feasibility of mapping the ecological optimum [54]. In addition, a comparison among putative refugia, already identified in previous studies [55], and their relative positions within the cork oak climatogram revealed a match with the maximum density of species presence. In fact, the 22 areas are mostly placed in the bottom-right part of the climatogram (see Figure 4), but the GCMs projections for the coming century reveal a global shift towards drier and warmer conditions. On the other hand, the species occurrence in the early 20th century is not detailed and widely referenced; thus, the comparison with the actual range is hard to assess. However, we can assume that variation in the distribution in a century is not significant for a long-life tree, such as cork oak, so the responses to climate change can be stated by recent investigations about tree dieback and changes in regeneration processes [56-59]. However, we can presently deal with advanced remote sensing techniques, which are useful to obtain punctual and refined data; by coupling that information with indexes, such as Emberger's Index, it is finally possible to monitor the responses of forest species to variations in climate, at least for the next century. This allows us to better understand the ecological amplitude and vulnerabilities of a target species [60,61]. Prediction models of climate might even be employed for future reforestation and restoration activities, and they might be able to output a more comprehensive framework of the future distribution of a species when used in niche modelling approaches [62]. However, the application of a synthetic index, such as Emberger's Index, as a user-friendly tool, provides a refined approximation of species distribution models by using only two variables.

The Joint Research Centre, on behalf of the European Commission, launched the European Atlas of Forest Tree Species, with insights into the distribution and suitability maps of the main tree species for the next century; the cork oak is obviously included [63], and its relative probability of presence was estimated using local bioclimatic conditions. Additional positive feedback might concern the combination of those models with Emberger's climatograms, so choosing the species for a given area could be performed by selecting those plants with optimal plasticity and physiologic characteristics.

Genetic information from previous studies has improved the possibility of exploring the behavior of species, even at the haplotype level. Once the correlation between genetic features and environmental variables is assessed, models can be developed to select the most effective haplotypes or provenances of a given species to be used. Attempts to detect the regions of provenance of forest species, based on genetics, already exist and refer to several species in Europe [64-66]. Further implementations can include the edaphic adaptability of a species with its Emberger climatogram [67]. Finally, this study might serve as exhortation to obtain more accurate species distribution maps, which are currently commonly lacking in forestry studies, but are fundamental to approach many investigations. 


\begin{abstract}
Supplementary Materials: The following are available online at https: / www.mdpi.com/article/ 10.3390/f13020252/s1, Supplementary Materials 1: Q-m diagrams showing the relative position of real distribution of cork oak forests (green points cloud) within the Daget's Mediterranean isoclimate (grey points cloud) at present time (A), 2050 (B), 2070 (C). Each point of the clouds represents a surface of 30 arc-seconds (ca. $1 \mathrm{~km}^{2}$ ); Supplementary Materials 2: Insert Q-m values to get the suitability class of a site.
\end{abstract}

Author Contributions: Conceptualization, B.S.; methodology, all authors; software, F.V.; original draft preparation, writing, review and editing, all authors. All authors have read and agreed to the published version of the manuscript.

Funding: This research received no external funding.

Conflicts of Interest: The authors declare no conflict of interest.

\title{
References
}

1. Daget, P.H. Le bioclimat Mediterraneen: Caractères généraux, modes de caractérisation. Vegetatio 1977, 34, 1-20. [CrossRef]

2. Aschmann, H. A restrictive definition of Mediterranean climates. Bull. Soc. Bot. Fr. Act. Bot. 1984, 131, 21-30. [CrossRef]

3. Trigo, R.; Xoplaki, E.; Zorita, E.; Luterbacher, J.; Krichak, S.O.; Alpert, P.; Jacobeit, J.; Sáenz, J.; Fernández, J.; González-Rouco, F.; et al. Relations between variability in the Mediterranean region and mid-latitude variability. In Developments in Earth and Environmental Sciences; Lionello, P., Malanotte-Rizzoli, P., Boscolo, R., Eds.; Elsevier: Amsterdam, The Netherlands, 2006; Volume 4, pp. 179-226. [CrossRef]

4. Köppen, W. Une nouvelle classification générale des climats. Rev. Gen. Sc. 1918, 30, 550-554.

5. Emberger, L. Les limites de l'aire de végétation méditerranéenne en France. Bull. Soc. Hist. Nat. Toul. 1943, 78, 158-180.

6. Aschmann, H. Distribution and peculiarity of Mediterranean ecosystems. In Mediterranean Type Ecosystems; Springer: Berlin/Heidelberg, Germany, 1973; pp. 11-19.

7. Giacobbe, A. Schema di una teoria ecologica per la classificazione della vegetazione italiana. Plant Biosyst. 1938, 45, 37-121. [CrossRef]

8. Bérenger, M. Mémorial de la Météorologie Nationale: Essai d’Etude Météorologique du Bassin Méditerranéen; Imp. Nationale: Paris, France, 1955.

9. Quézel, P. Definition of the Mediterranean region and the origin of its flora. In Plant Conservation in the Mediterranean Area. Geobotany 7; Gomez-Campo, C., Ed.; W. Junk: Dordrecht, The Netherlands; Boston, MA, USA; Lancaster, UK, 1985 ; pp. 9-24.

10. Quézel, P.; Barbero, M. Carte de la Végétation Potentielle de la Région Méditerranéenne: Feuille $n^{\circ} 1$ Méditerranée Orientale; Ed. du Centre National de la Recherche Scientifique (CNRS): Paris, France, 1985.

11. Médail, F.; Quézel, P. Hot-spots analysis for conservation of plant biodiversity in the Mediterranean Basin. Ann. Mo. Bot. Gard. 1997, 84, 112-127. [CrossRef]

12. Rivas-Martínez, S.; Penas, A.; Díaz, T.E. Bioblimatic Map of Europe. Cartographic Service; University of Léon: Leon, Spain, 2004.

13. Mitrakos, K. A theory for Mediterranean plant life. Acta Oecol. 1980, 1, 245-252.

14. Emberger, L. La végétation de la Région Méditerranéenne: Essai d'une classification des groupenments végétaux. Rev. Génerale Bot. 1930, 42, 642-662.

15. Sauvage, C. Le quotient pluviothermique d'Emberger, son utilisation et la representation géographique de ses variations au Maroc. Ann. Phys. Globe Météo Inst. Sci Chérif. 1963, 20, 11-23.

16. Le Houérou, H.N. An outline of the bioclimatology of Libya. Bull. Société Bot. Fr. Actual. Bot. 1984, 131, 157-178. [CrossRef]

17. Gavilán, R.G. The use of climatic parameters and indices in vegetation distribution. A case study in the Spanish Sistema Central. Int. J. Biometeorol. 2005, 50, 111-120. [CrossRef] [PubMed]

18. Rego, F.C.; Rocha, M.S. Climatic patterns in the Mediterranean region. Ecol. Mediterr. 2014, 40, 49-59. [CrossRef]

19. Haghighi, A.T.; Zaki, N.A.; Rossi, P.M.; Noori, R.; Hekmatzadeh, A.A.; Saremi, H.; Kløve, B. Unsustainability Syndrome-From meteorological to agricultural drought in arid and semi-arid regions. Water 2020, 12, 838. [CrossRef]

20. Nikolova, N.; Yanakiev, D. Climate aridity in southern Bulgaria for the period 1961-2015. Forum Geografic. Stud. Cercet. Geogr. Protectia Mediu. 2020, XIX, 10-17. [CrossRef]

21. Golvan, Y.; Rioux, J. Ecologie des mérions du Kurdistan Iranien: Relations avec l'épidémiologie de la peste rurale. Ann. Par. Hum. Comp. 1961, 36, 449-558. [CrossRef]

22. Despois, J.; Raynal, R. Géographie de l'Afrique du Nord-Ouest; Payot: Paris, France, 1967; Volume 26.

23. Dumroese, R.K.; Palik, B.J.; Stanturf, J.A. Forest restoration is forward thinking. J. For. 2015, 113, 430-432. [CrossRef]

24. Schirone, B.; Radoglou, K.; Vessella, F. Conservation and restoration strategies to preserve the variability of cork oak Quercus suber-A Mediterranean forest species-under global warming. Clim. Res. 2017, 71, 171-185. [CrossRef]

25. Nahal, I. Le Pin d'Alep (Pinus halepensis Mill.). 1962, Étude taxonomique, phytogéographique, écologique et sylvicole. Ann. Ecole Nat. Eaux For. Stat. Rech. Exp. For. 1962, 19, 477-688.

26. Quezel, P. Les forêts du pourtour méditerranéen. In Forêts et Maquis Méditerranéens: Écologie, Conservation et Aménagement; Note Technique MAB, 2; UNESCO: Paris, France, 1976; pp. 9-33. 
27. Daget, P. Le Bioclimat Mediterraneen: Analyse des formes climatiques par le systeme d'Emberger. Vegetatio 1977, $34,87-103$. [CrossRef]

28. Quézel, P.; Tomaselli, R.; Morandini, R. Bosque y Maquia Mediterráneos: Ecología, Conservación y Gestión [Mediterranean Forest and Maquis: Ecology, Conservation and Management]; Serbal/UNESCO: Paris, France, 1977; Volume 333.75. Q5.

29. Guara Requena, M.; Laguna Lumbreras, E.; Sanchis Duato, E. Aproximacion cartografica a la distribucion del indice de Emberger en la Comunidad Valenciana. Collect. Bot. Barcinonensi Bot. Inst. Ed. 1986, 16, 355-363.

30. Quézel, P.; Médail, F. Ecologie et Biogéographie des Forêts du Bassin Méditerranéen: Collection Environnement; Elsevier: Paris, France, 2003.

31. Dufour-Dror, J.M.; Ertas, A. Bioclimatic perspectives in the distribution of Quercus ithaburensis Decne. subspecies in Turkey and in the Levant. J. Biogeogr. 2004, 31, 461-474. [CrossRef]

32. Klausmeyer, K.R.; Shaw, M.R. Climate change, habitat loss, protected areas and the climate adaptation potential of species in Mediterranean ecosystems worldwide. PLoS ONE 2009, 4, e6392. [CrossRef] [PubMed]

33. IPCC. Climate Change: Synthesis Report. Contribution of Working Groups I, II and III to the Fifth Assessment Report of the Intergovernmental Panel on Climate Change; IPCC: Geneva, Switzerland, 2014.

34. Aronson, J.; Pereira, J.S.; Pausas, J.G. Cork Oak Woodlands on the Edge: Ecology, Adaptive Management, and Restoration; Island Press: Washington, DC, USA; Covelo, Italy; London, UK, 2009.

35. Magri, D.; Fineschi, S.; Bellarosa, R.; Buonamici, A.; Sebastiani, F.; Schirone, B.; Simeone, M.C.; Vendramin, G.G. The distribution of Quercus suber chloroplast haplotypes matches the palaeogeographical history of the western Mediterranean. Mol. Ecol. 2007, 16, 5259-5266. [CrossRef]

36. Vessella, F.; Simeone, M.C.; Schirone, B. Quercus suber range dynamics by ecological niche modelling: From the Last Interglacial to present time. Quat. Sci Rev. 2015, 119, 85-93. [CrossRef]

37. Correia, A.; Costa-e-Silva, F.; Dubbert, M.; Piayda, A.; Pereira, J. Severe dry winter affects plant phenology and carbon balance of a cork oak woodland understorey. Acta Oecol. 2016, 76, 1-12. [CrossRef]

38. Simeone, M.C.; Papini, A.; Vessella, F.; Bellarosa, R.; Spada, F.; Schirone, B. Multiple genome relationships and a complex biogeographic history in the eastern range of Quercus suber L. (Fagaceae) implied by nuclear and chloroplast DNA variation. Caryologia 2009, 62, 236-252.

39. Emberger, L. Nouvelle contribution à l'étude de la classification des groupements végétaux. Rev. Gén. Bot. 1933, 45, 473-486.

40. Hijmans, R.J.; Cameron, S.E.; Parra, J.L.; Jones, P.G.; Jarvis, A. Very high resolution interpolated climate surfaces for global land areas. Int. J. Climatol. 2005, 25, 1965-1978. [CrossRef]

41. Araújo, M.B.; Cabeza, M.; Thuiller, W.; Hannah, L.; Williams, P.H. Would climate change drive species out of reserves? An assessment of existing reserve-selection methods. Glob. Change Biol. 2004, 10, 1618-1626. [CrossRef]

42. Thomas, C.D.; Cameron, A.; Green, R.E.; Bakkenes, M.; Beaumont, L.J.; Collingham, Y.C.; Erasmus, B.F.; De Siqueira, M.F.; Grainger, A.; Hannah, L. Extinction risk from climate change. Nature 2004, 427, 145-148. [CrossRef]

43. Thuiller, W.; Lavorel, S.; Araújo, M.B.; Sykes, M.T.; Prentice, I.C. Climate change threats to plant diversity in Europe. Proc. Natl. Acad. Sci. USA 2005, 102, 8245-8250. [CrossRef]

44. Carnicer, J.; Colla, M.; Ninyerola, M.; Pons, X.; Sánchez, G.; Peñuelas, J. Widespread crown condition decline, food web disruption, and amplified tree mortality with increased climate change-type drought. Proc. Natl. Acad. Sci. USA 2011, 108, 1474-1478. [CrossRef]

45. Schirone, B.; Al-Hirsh, I.; Al-Qaddi, N.; Battisti, C.; Vessella, F.; Marras, T.; Ortolani, R.M. Parallel disasters: Wars and biodiversity loss in mountain areas. Reforesta 2016, 1, 76-80. [CrossRef]

46. Bonan, G.B. Forests and climate change: Forcings, feedbacks, and the climate benefits of forests. Science 2008, 320, 1444-1449. [CrossRef]

47. Stanturf, J.A.; Palik, B.J.; Williams, M.I.; Dumroese, R.K.; Madsen, P. Forest restoration paradigms. J. Sustain. For. 2014, 33, S161-S194.

48. Dumroese, R.K.; Williams, M.I.; Stanturf, J.A.; Clair, J.B.S. Considerations for restoring temperate forests of tomorrow: Forest restoration, assisted migration, and bioengineering. New For. 2015, 46, 947-964. [CrossRef]

49. Artz, R.; Anastasoiu, D.; Arrouays, D.; Bastos, A.; Benedetti, A.; Pagliai, M. European Atlas of Soil Biodiversity; Publication Office of the European Union: Luxembourg, 2010.

50. Caloiero, T.; Callegari, G.; Cantasano, N.; Coletta, V.; Pellicone, G.; Veltri, A. Bioclimatic analysis in a region of southern Italy (Calabria). Plant Biosyst. 2016, 150, 1282-1295. [CrossRef]

51. Barrón, L.G.; Morales, J.; Sousa, A. Time analysis of Emberger's Pluviothermic Q Index in the SW of the Iberian Peninsula. In Patterns and Mechanisms of Climate, Paleoclimate and Paleoenvironmental Changes from Low-Latitude Regions, Proceedings of the Conference of the Arabian Journal of Geosciences (CAJG-1), Sousse, Tunisia, 12-15 November 2018; Zhang, Z., Khélifi, N., Mezghani, A., Heggy, E., Eds.; Springer: Berlin/Heidelberg, Germany, 2019; pp. 45-47.

52. FAO; CIFOR. FAO Framework Methodology for Climate Change Vulnerability Assessments of Forests and Forest Dependent People; Forestry Paper 183; FAO: Rome, Italy, 2019.

53. Balekoglu, S.; Caliskan, S.; Dirik, H. Effects of geoclimatic factors on the variability in Pinus pinea cone, seed, and seedling traits in Turkey native habitats. Ecol. Process. 2020, 9, 55. [CrossRef] 
54. Van Couwenberghe, R.; Collet, C.; Pierrat, J.-C.; Verheyen, K.; Gégout, J.-C. Can species distribution models be used to describe plant abundance patterns? Ecography 2013, 36, 665-674. [CrossRef]

55. Médail, F.; Diadema, K. Glacial refugia influence plant diversity patterns in the Mediterranean Basin. J. Biogeogr. 2009, 36, 1333-1345. [CrossRef]

56. Acácio, V.; Dias, F.S.; Catry, F.X.; Bugalho, M.N.; Moreira, F. Canopy cover loss of Mediterranean oak woodlands: Long-term effects of management and climate. Ecosystems 2021, 24, 1775-1791. [CrossRef]

57. Montero-Muñoz, J.L.; Ureña, C.; Navarro, D.; Herrera, V.; Alonso-Rojo, P.; Hernández-Alonso, H.; Cepeda-González, M.F.; Jovellar, L.C.; Fernández-Santos, B.; Silla, F. Regeneration dynamics in fragmented landscapes at the leading edge of distribution: Quercus suber woodlands as a study case. Plant Soil 2021, 467, 311-327. [CrossRef]

58. Rossetti, I.; Bagella, S. Mediterranean Quercus suber wooded grasslands risk disappearance: New evidences from Sardinia (Italy). For. Ecol. Manag. 2014, 329, 148-157. [CrossRef]

59. Touhami, I.; Chirino, E.; Aouinti, H.; El Khorchani, A.; Elaieb, M.T.; Khaldi, A.; Nasr, Z. Decline and dieback of cork oak (Quercus suber L.) forests in the Mediterranean basin: A case study of Kroumirie, Northwest Tunisia. J. For. Res. 2020, 31, 1461-1477. [CrossRef]

60. Condés, S.; García-Robredo, F. An empirical mixed model to quantify climate influence on the growth of Pinus halepensis Mill stands in South-Eastern Spain. For. Ecol. Manag. 2012, 284, 59-68. [CrossRef]

61. Aabdousse, J.; Wahid, N.; Faida, R.; Karaoui, I.; Boulli, A.; Hassib, A. Determination of the effect of biogeographic variability on myrtle ecology in Morocco using a combination of GIS and bioclimatic indices. J. Mater. Environ. Sci. 2021, 12, 1209-1225.

62. Vessella, F.; López-Tirado, J.; Simeone, M.C.; Schirone, B.; Hidalgo, P.J. A tree species range in the face of climate change: Cork oak as a study case for the Mediterranean biome. Eur. J. For. Res. 2017, 136, 555-569. [CrossRef]

63. Houston Durrant, T.; de Rigo, D.; Caudullo, G. Quercus suber in Europe: Distribution, habitat, usage and threats. In European Atlas of Forest Tree Species; San-Miguel-Ayanz, J., de Rigo, D., Caudullo, G., Houston Durrant, T., Mauri, A., Eds.; Publication Office of the European Union: Luxembourg, 2016; p. e01ff11.

64. Alía, R.; Gómez, A.; Agúndez, M.; Bueno, M.; Notivol, E. Levels of genetic differentiation in Pinus halepensis Mill. in Spain using quantitative traits, isozymes, RAPDs and cp-microsatellites. In Genetic Response of Forest Systems to Changing Environmental Conditions; Springer: Dordrecht, The Netherlands, 2001; pp. 151-160.

65. Derory, J.; Mariette, S.; Gonzaléz-Martínez, S.C.; Chagné, D.; Madura, D.; Gerber, S.; Brach, J.; Persyn, F.; Ribeiro, M.M.; Plomion, C. What can nuclear microsatellites tell us about maritime pine genetic resources conservation and provenance certification strategies? Ann. For. Sci. 2002, 59, 699-708. [CrossRef]

66. Martín, J.; Esteban, L.; de Palacios, P.; Fernandez, F.G. Variation in wood anatomical traits of Pinus sylvestris L. between Spanish regions of provenance. Trees 2010, 24, 1017-1028. [CrossRef]

67. Reis, F.; Soares-Castro, P.; Costa, D.; Tavares, R.M.; Baptista, P.; Santos, P.M.; Lino-Netoa, T. Climatic impacts on the bacterial community profiles of cork oak soils. Appl. Soil Ecol. 2019, 143, 89-97. [CrossRef] 